\title{
SEROSURVEY OF PATHOGENIC HANTAVIRUSES AMONG FORESTRY WORKERS IN HUNGARY
}

\section{MIKLÓS OLDAL ${ }^{1,2}$, VIKTÓRIA NÉMETH ${ }^{1,2}$, MÓNIKA MADAI ${ }^{1,2}$, RÉKA PINTÉR ${ }^{1,2}$, GÁBOR KEMENESI ${ }^{1,2}$, BIANKA DALLOS ${ }^{1,2}$, ANNA KUTAS ${ }^{1,2}$, JUDIT SEBŐK³, GYŐZŐ HORVÁTH², KRISZTIÁN BÁNYAI, and FERENC JAKAB ${ }^{1,2}$}

${ }^{1}$ University of Pécs, Pécs, Hungary

Szentágothai Research Center, Virological Research Group

${ }^{2}$ University of Pécs, Pécs, Hungary

Faculty of Sciences, Institute of Biology

${ }^{3}$ University of Pécs, Pécs, Hungary

Medical School, 2nd Department of Internal Medicine and Nephrology Center

${ }^{4}$ Hungarian Academy of Sciences, Budapest, Hungary

Center for Agricultural Research, Veterinary Medical Research Institute

\begin{abstract}
Objectives: The aim of the study was to survey the prevalence of human hantavirus infections among forestry workers, who are considered a risk population for contracting the disease. Sera collected from volunteers were tested for antibodies against Dobrava-Belgrade (DOBV) and Puumala (PUUV) viruses. Material and Methods: For serological analyses, full capsid proteins of DOBV and PUUV viruses were produced in a bacterial expression system, while Ni-resin was used for protein purification. Samples were screened for anti-hantavirus antibodies by ELISA, results were confirmed by Western blot analysis. Results: A total of 835 samples collected from 750 males and 85 females were tested by indirect ELISA and positive test results were confirmed by Western blot assay. Out of the 45 ELISA-reactive samples, 38 were confirmed by Western blot analysis. The regional distribution of seropositive individuals was as follows: $1.9 \%(2 / 107)$ in the Danube-Tisza Plateau (Great Plains), 3.1\% (10/321) in the Southern Transdanubian region, 5.2\% (13/248) in the Northern Transdanubian, and $8.2 \%$ (13/159) in the North Hungarian Mountains. Conclusions: Our data show marked geographic differences in seroprevalence of pathogenic hantaviruses within Hungary, indicating elevated exposure to hantavirus infections in some areas.
\end{abstract}

Key words:

Hantavirus, Forestry, Serosurvey, Western blot, Hungary

\section{INTRODUCTION}

Hantaviruses, as members of the Bunyaviridae family, are potential human pathogens with rodent and insectivore host species. Hantaviruses circulating in Asia and Europe are collectively called Old World hantaviruses; these agents are usually connected with the disease called hemorrhagic fever with renal syndrome (HFRS), with varying case fatality rates ranging from $0.1-15 \%$ [1]. Next to the

Research activity of Ferenc Jakab was supported by the TÁMOP 4.2.4. A/2-11-1-2012 0001 - National Excellence Program Elaborating and Operating an Inland Student and Researcher Personal Support System. The project was subsidized by the European Union and co-financed by the European Social Fund. This study was supported by the Hungarian Scientific Research Fund (OTKA; PD77977) project. Krisztián Bányai was supported by the "Momentum program."

Received: March 13, 2014. Accepted: June 5, 2014.

Corresponding author: F. Jakab, Virological Research Group, János Szentágothai Research Center, University of Pécs, Ifjúság út 20, H-7624, Pécs, Hungary (e-mail: jakabf@gamma.ttk.pte.hu). 
usual kidney involvement, European hantaviruses may also cause pulmonary symptoms, similarly to the symptoms caused by New World hantaviruses [2-5]. Hence, the term "hantavirus disease" has recently been introduced in clinical nomenclature to cover all clinical manifestations provoked by hantaviruses [6-8]. Disease severity strongly correlates with the causative hantavirus species.

Old World hantaviruses include several species and genotypes within a species. Dobrava-Belgrade virus (DOBV) species has 4 genotypes, each segregating according to the murine host species. Dobrava and Sochi genotypes are carried by yellow-necked mouse (Apodemus flavicollis), and Caucasian wood mouse (A. ponticus), while Saaremaa and Kurkino genotypes are transmitted by striped field mouse (A. agrarius). Puumala hantavirus (PUUV) is associated with nephropathia epidemica (NE), a mild form of HFRS, with bank vole (Myodes glareolus) as host species. Tula virus (TULV) was identified in common vole (Microtus arvalis), and was suspected to be a rare cause of hantavirus disease in humans [9-12].

In Hungary, HFRS was first observed in the early 1950s among military personnel. HRFS with verified hantavirus origin was reported officially in 1971 [13]. Routine laboratory diagnosis was launched in the early 80 's. Between 1987 and 1993, the Hungarian Army Medical Corps confirmed HFRS in 55 patients by indirect fluorescent antibody technique (IFAT), high density particle agglutination (HDPA) and enzyme-linked immunosorbent assay (ELISA) techniques [14]. Later on, case reports and clinical studies revealed that DOBV was often found as a causative agent of identified hantavirus infections in the country [15-17].

The circulation of DOBV in Hungary was proven by molecular methods already in 1995 and somewhat later, the circulation of 3 DOBV genotypes was confirmed [18-20]. In 2008, the presence of TULV was also verified in the Transdanubian region by molecular methods in Microtus arvalis voles [21]. Additional hantavirus diversity was described in Hungarian insectivorous mammals, such as Nova virus (NVAV) in the European common mole (Talpa europaea) [22], and Seewis (SWSV) virus, which was identified in European common shrew (Sorex araneus) [23]. Hunters and forestry workers represent a risk population for hantavirus infections due to their increased exposure to various rodents carrying different pathogenic hantavirus species. Studies focusing on hantavirus seroprevalence in this risk population were carried out in several European countries, including Slovakia, Poland, Switzerland and Germany [24-28]. This occupational risk has not been systematically investigated in Hungary; hence, we aimed to study hantavirus infections by demonstrating DOBV and PUUV specific antibodies in serum samples of hunters and forestry workers.

\section{MATERIAL AND METHODS}

\section{Volunteers and samples}

Serum samples were collected from volunteer forestry workers, between June 2011 and February 2013. All volunteers provided a signed consent and were asked to fill out a questionnaire containing the following aspects: epidemiological data (i.e., age, place of birth and living), exact work duties, work time in forestry and on-field, previous zoonotic infections, animal contacts, domestic animals kept, medication received as well as drugs taken. Factors in context of possible hantavirus preludes were also recorded, i.e., unclarified severe renal complaints and diseases with high fever. All kinds of manipulation with potentially infectious materials were carried out in a BSL-3 facility of the University of Pécs. Study was approved by the National Medical Scientific Ethical Board (ETT-TUKEB No\#2213-0/2010-1018EKU).

\section{Combined DOBV-PUUV specific ELISA}

For ELISA and Western blot (WB) analysis, we applied recombinant DOBV and PUUV antigens, both produced 
in an Escherichia coli bacterial expression system, as described previously [29]. Microtiter plates (Maxisorp NuncImmuno Plate, Nunc) were coated with a combination of DOBV and PUUV antigens, followed by incubation for $2 \mathrm{~h}$ at $37^{\circ} \mathrm{C}$. Excess antigens were removed by washing with phosphate-buffered saline (PBS) $(\mathrm{pH}=7.5)$, containing $0.05 \%$ Tween-20 (Sigma) (PBS-T). Microtiter plates were blocked for $2 \mathrm{~h}$ at $37^{\circ} \mathrm{C}$, using PBS containing 5\% non-fat dry milk (Blotting-Grade Blocker, BIO-RAD) and 5\% sucrose (Merck). Volunteers' sera were used in 1:100 dilutions in PBS containing $2.5 \%$ non-fat dry milk. Serum samples of patients previously verified for DOBV and PUUV infections, respectively, were used as positive control. After incubation for $1 \mathrm{~h}$ at $37^{\circ} \mathrm{C}$, microtiter plates were washed with PBS-T. Horseradish peroxidase-conjugated rabbit anti-human $\operatorname{IgG}$ (DakoCytomation) was used as secondary antibody, diluted to 1:4000 in PBS-T. Plates were incubated at $37^{\circ} \mathrm{C}$ for $1 \mathrm{~h}$, followed by washing again with PBS-T. Colour development was allowed using $100 \mu \mathrm{l}$ of 3,3',5,5'-tetreamethylbenzidine substrate (BD OptEIA), incubating at room temperature in the dark for $15 \mathrm{~min}$. The reaction was stopped by the addition of $100 \mu \mathrm{l}$ of $2 \mathrm{M}$ sulfuric acid, and optical density was measured on a microplate spectrophotometer (Thermo Electron Corporation) at $450 \mathrm{~nm}$.

The cut-off (CO) value was calculated as described previously by Dobly et al. [30]. Briefly: the average optical density (OD) of negative control sera plus 3 times their standard deviation. We compared series by calculating the ratio: observed $\mathrm{OD} / \mathrm{CO}$. A sample was considered positive if this ratio was at least 1.5 . Ratios between 1.0 and 1.5 were considered "grey zone" values, while samples with ratio lower than 1 were considered to be negative.

\section{Western blot assay}

All samples considered as positive (with high or "grey zone" OD values) were confirmed by immunoblot analysis, against both DOBV and PUUV nucleocapsid proteins. Nucleocapsid proteins of DOBV and PUUV were loaded into the wells of Mini-PROTEAN ${ }^{\circledR}$ Precast Gels (BIO-RAD). After electrophoresis, proteins were transferred to $0.45 \mu \mathrm{m}$ pore size nitrocellulose membranes (BIO-RAD), using Trans-Blot ${ }^{\circledR}$ SD Semi-Dry Electrophoretic Transfer Cell (BIO-RAD), at $170 \mathrm{~mA}$ for $30 \mathrm{~min}$. After blocking for $30 \mathrm{~min}$ with $5 \%$ non-fat dry milk (Blotting-Grade Blocker, BIO-RAD), sera were applied in 1:100 dilution using tris-buffered saline (TBS) $(\mathrm{pH}=7.5)$, containing $0.1 \%$ bovine serum albumin and $0.05 \%$ Tween-20 (Sigma). Horseradish peroxidase-conjugated rabbit anti-human IgG (1:2000, DakoCytomation) was used as secondary antibody. All incubation steps were executed at room temperature for 1 hour. Three consecutive 10 min washing steps were implemented using 1x TBS-Tween-20 (pH = 7.5). Development was carried out using diamino-benzidine in $50 \mathrm{mM}$ Tris $(\mathrm{pH}=7.5)$, containing $0.3 \%$ Nickel(II) chloride (Sigma).

\section{ELISA and Western blot validation}

Specificity and sensitivity were measured as described previously [17]. Briefly, specificity and sensitivity was determined comparing our in-house ELISA and WB analysis results to those obtained by a commercially available ELISA kit (Focus Diagnostics), specific for DOBV, Hantaan, PUUV and Seoul viruses.

\section{Statistical analyses}

For comparison of proportions, the $\mathrm{Chi}^{2}$ test was applied. Difference of $p \leq 0.05$ was considered as statistically significant for each analysis.

\section{RESULTS}

As a first step, protein expression products to be used in serological screenings were characterized. Polyacrylamide gel electrophoresis as well as microfluidic-based analyses revealed 55 and $59 \mathrm{kDa}$-sized recombinant nucleocapsid proteins for DOBV and PUUV, respectively. 
As an introductory step, specificity and sensitivity values for ELISA and WB tests were verified. The same sample set was tested in parallel with ELISA, WB assay and a commercially available ELISA kit. The sensitivity of ELISA and WB for both DOBV and PUUV was $100 \%$. The specificity of WB for DOBV was $100 \%$, while it was $97.5 \%$ for PUUV. The ELISA assay had a specificity of $93 \%$ for both viral antigens.

In total, 835 blood samples were collected from healthy volunteer forestry workers, personnel of 106 sylvicultures in 9 Hungarian counties. The 750 males (range: 18-70) and 85 females (range: 23-59) had an average age of 45 years, with 25 years (range: 0.1-51) of field work on average. The initial screening of the 835 serum samples in IgG ELISAs using mixed PUUV and DOBV antigens demonstrated a total of 45 (5.4\%) reactive and equivocal sera. Serological reactivity for 38 (4.6\%) of the 45 ELISAreactive sera was confirmed in Western blot tests, the resulting 38 sera were regarded as seropositive.

A map displaying seroprevalence data was constructed, by dividing the country area to 4 main regions, which correspond to the field work area of donors. The main areas are the following: Northern Transdanubian region (I), Southern Transdanubian region (II), the Danube-Tisza Plateau (III) and the North Hungarian Mountains (IV) (Figure 1). The regional seroprevalence values were the following: $1.9 \%(2 / 107)$ in region III, $3.1 \%(10 / 321)$ in region II, 5.2\% (13/248), in region I, and 8.2\% (13/159) in region IV (Table 1). Chi ${ }^{2}$ test revealed that seroprevalence

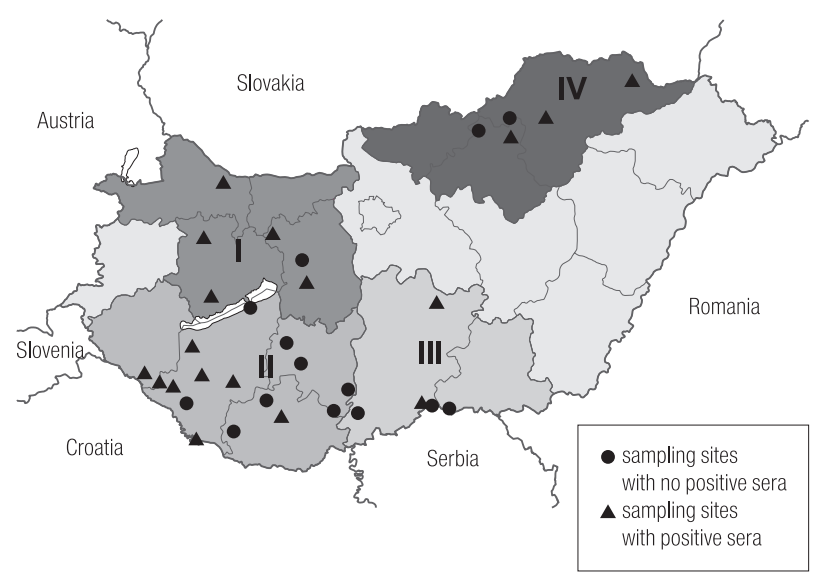

I - Northern Transdanubian region.

II - Southern Transdanubian region.

III - Danube-Tisza Plateau.

IV - North Hungarian Mountains.

Fig. 1. Location of blood sampling sites and regions in Hungary in region IV was significantly higher than in regions II and III $(\mathrm{p}<0.05)$.

Hantavirus-specific antibody prevalence was 3\% (23/750), and $2.4 \%(2 / 85)$ among males and females, respectively. The average ages of seropositive men and women were 44 years and 43 years, respectively. In 4 cases, anamnesis records could be connected to hantavirus etiology, with symptoms and findings of renal colic, elevated serum creatinine (above $300 \mu \mathrm{mol} / \mathrm{l}$ ), nephritis, urinary problems, and also dialysis treatment in 1 person. In all these cases, renal involvement was considered idiopathic at the time of emergence, the underlying cause was not clarified.

Table 1. Prevalence of hantavirus antibodies in the study areas by serological tests

\begin{tabular}{lcccc}
\hline \multicolumn{1}{c}{ Study area } & $\begin{array}{c}\text { Sampling site } \\
(\mathrm{n})\end{array}$ & $\begin{array}{c}\text { Sample } \\
(\mathrm{N}=835) \\
(\mathrm{n})\end{array}$ & $\begin{array}{c}\text { Positive } \\
(\mathrm{n})\end{array}$ & $\begin{array}{c}\text { Seroprevalence } \\
(\%)\end{array}$ \\
\hline Danube-Tisza Plateau (III) & 5 & 107 & 2 & 1.9 \\
Southern Transdanubian region (II) & 16 & 321 & 10 & 3.1 \\
Northern Transdanubian region (I) & 6 & 248 & 13 & 5.2 \\
North Hungarian Mountains (IV) & 5 & 159 & 13 & 8.2 \\
Total & 32 & 835 & 38 & 4.6 \\
\hline
\end{tabular}




\section{DISCUSSION}

The current study revealed a relatively high seropositive rate for hantaviruses among forestry workers in the North Hungarian Mountains (IV). The difference between areas IV and III was 4-fold. Because the source of hantavirus infections in humans are rodents, this area specific difference may reflect differences in the exposure to infected rodents. In Hungary, rodent hosts for DOBV are Apodemus flavicollis and A. agrarius, while PUUV is carried by Myodes glareolus. Although the habitat of $A$. agrarius includes forests as well as agricultural areas, the remaining 2 host species, especially $A$. flavicollis typically prefer large, montane woodlands for habitats [31,32].

Our findings seem to correlate with the latter, as the highest seroprevalence values in this study were detected in the large mountain woodlands of regions IV and I. Statistical test results also confirmed that significant difference was only found when comparing region IV to regions II and III, the latter 2 being hilly and lowland regions. The considerably lower prevalence value in region III is probably related to the relatively small and open forest patches, where populations of $A$. agrarius, A. flavicollis, and M. glareolus gets mixed with additional rodent and shrew species.

It is interesting to compare these latest results to a former large-scale study from Hungary. A national serosurvey was carried out in 2000, when 2257 citizens were tested for antibodies against hantavirus using IFAT, HDPA and ELISA. Results indicate that about $10 \%$ of healthy people can be considered seropositive. Affected persons lived in all areas of the country [33]. Persons tested at that time were not restricted to the "risk population" discussed here, but were selected on a basis only to cover the majority of the country area and being older than 20 years. In the light of our results, the $5.4 \%$ disparity in total seroprevalence represents a marked discrepancy. Possible explanations for this observation include the differences in sensitivity and specificity of test results utilized in the present and the past serosurvey. Our screening (ELISA) and confirmation (WB) methods were carefully optimized and were based on recombinant viral nucleocapsid antigens that were produced utilizing up-to-date molecular biological systems.

Studies similar to our survey have been carried out in Europe to reveal hantavirus seroprevalence in forestry workers. In Slovakia, 2133 persons were involved in a screening for DOBV, PUUV and TULV hantaviruses. A 5.88\% seroprevalence was detected in the eastern part of the country [24]. In Germany, a corresponding work was carried out in the north-eastern Brandenburg territory, revealing that among a total of 563 tested persons, 9\% proved to be seropositive against DOBV, PUUV and TULV [28]. In Switzerland, the assaying of 1693 farmers, forestry workers, young soldiers and blood donors showed low seroprevalence rates with a maximum of $1.9 \%$. The study area was restricted to the Canton of St. Gallen [27]. There are 2 related studies from Poland. In the paper of Gut et al. 2007, panels of 86 sera from forest workers and 47 zoologists working with small mammals were evaluated for hantavirus specific $\operatorname{IgG}$. PUUV-specific antibodies were detected in 14.9\% (7/47) of zoologist's sera, while all sera of forestry workers were negative [25]. On the other hand, Grygorczuk et al. in 2008 found that in the north-eastern part of Poland, anti-PUUV IgG from forest worker sera was detected in $5.7 \%(4 / 69)$, while HTNV-specific IgG was present in $2.9 \%(2 / 69)$ persons [26].

Thus, comparing Hungary to other European countries with available data of hantavirus prevalence in forestry workers, we conclude that the occurrence of hantavirus infections is most similar to that of reported form Slovakia, at least in terms of the total seroprevalence. The data shown in the studies from Poland also demonstrate comparable values, although there is a large difference in the number of tested samples. The authors from Slovakia and Switzerland screened considerably more persons, 
whereas the study from Germany had the most comparable number of involved forestry workers. On the other hand, Germany experiences higher number of annual hantavirus infections than Hungary and the countries directly surrounding it $[34,35]$. Furthermore, TULV was included in the study from Germany and Slovakia showing that - at least in the federal state of Brandenburg more than $40 \%$ of the positive sera reacted exclusively with TULV.

Given those whole nucleocapsid proteins that contain both type-specific and type-common epitopes, our laboratory tests could not distinguish between DOBV and PUUV infections. Similar shortcomings apply to several commonly used commercial and in-house laboratory assays developed for hantavirus serology. Therefore, more precise data about the rates of infections caused by different pathogenic hantaviruses requires new methodological approaches.

\section{CONCLUSIONS}

Based on the results of our comprehensive investigation in Hungary, we assume that hantavirus seroprevalence among forestry workers is similar to that in Slovakia. Moreover, a greater attention might be paid to the to risk population for hantavirus infections in the future.

\section{ACKNOWLEDGEMENT}

We would like to thank Prof. Dr. med. Detlev H. Krüger (Charité - Universitätsmedizin Berlin), for kindly providing us positive control serums for Puumala hantavirus.

\section{REFERENCES}

1. Kruger DH, Ulrich R, Lundkvist A. Hantavirus infections and their prevention. Microbes Infect. 2001;3(13):1129-44, http:// dx.doi.org/10.1016/S1286-4579(01)01474-5.
2. Caramello P, Canta F, Bonino L, Moiraghi C, Navone F, Lipani F, et al. Puumala virus pulmonary syndrome in a Romanian immigrant. J Travel Med. 2002;9(6):326-9, http:// dx.doi.org/10.2310/7060.2002.30014.

3. Clement J, Colson P, McKenna P. Hantavirus pulmonary syndrome in New England and Europe. N Engl J Med. 1994;331(8):545-8, http://dx.doi.org/10.1056/NEJM19940825 3310813 .

4. Hoier S, Aberle SW, Langner C, Schnedl W, Hogenauer C, Reisinger EC, et al. Puumala virus RNA in patient with multiorgan failure. Emerg Infect Dis. 2006;12:356-7, http://dx.doi. org/10.3201/eid1202.050634.

5. Seitsonen E, Hynninen M, Kolho E, Kallio-Kokko H, Pettila V. Corticosteroids combined with continuous veno-venous hemodiafiltration for treatment of hantavirus pulmonary syndrome caused by Puumala virus infection. Eur J Clin Microbiol Infect Dis. 2006;25:261-6, http://dx.doi.org/10.1007/ s10096-006-0117-z.

6. Rasmuson J, Andersson C, Norrman E, Haney M, Evander M, Ahlm C. Time to revise the paradigm of hantavirus syndromes? Hantavirus pulmonary syndrome caused by European hantavirus. Eur J Clin Microbiol Infect Dis. 2011;30:685-90, http://dx.doi.org/10.1007/s10096-010-1141-6.

7. Clement J, Maes P, Lagrou K, van Ranst M, Lameire N. A unifying hypothesis and a single name for a complex globally emerging infection: Hantavirus disease. Eur J Clin Microbiol Infect Dis. 2012;31:1-5, http://dx.doi.org/10.1007/s10096011-1456-y.

8. Clement J, Maes P, van Ranst M. Hemorrhagic fever with renal syndrome in the new, and hantavirus pulmonary syndrome in the old world: Paradi(se)gm lost - or regained? Virus Res. 2014;187:55-8, http://dx.doi.org/10.1016/j.virusres. 2013.12.036.

9. Klempa B, Meisel H, Rath S, Bartel J, Ulrich R, Kruger DH. Occurrence of renal and pulmonary syndrome in a region of northeast Germany where Tula hantavirus circulates. J Clin Microbiol. 2003;41(10):4894-7, http://dx.doi.org/10.1128/JC M.41.10.4894-4897.2003. 
10. Zelená H, Mrázek J, Kuhn T. Tula hantavirus infection in immunocompromised host, Czech Republic. Emerg Infect Dis. 2013;19(11):1873-5, http://dx.doi.org/10.3201/eid 1911.130421.

11. Schultze D, Lundkvist A, Blauenstein U, Heyman P. Tula virus infection associated with fever and exanthema after a wild rodent bite. Eur J Clin Microbiol Infect Dis. 2002; 21(4):304-6, http://dx.doi.org/10.1007/s10096-002-0705-5.

12. Clement J, Frans J, van Ranst M. Human Tula virus infection or rat-bite fever? Eur J Clin Microbiol Infect Dis. 2003;22(5):332-3.

13. Trencséni T, Keleti B. Clinical aspects and epidemiology of haemorrhagic fever with renal syndrome: Analysis of clinical and epidemiological experiences in Hungary. Budapest: Akadémiai Kiadó; 1971.

14. Faludi G, Ferenczi E. Serologically verified hantavirus infections in Hungary. Acta Microbiol Immunol Hung. 1995;42(4):419-26.

15. Jakab F, Sebok J, Ferenczi E, Horváth G, Szucs G. First detection of Dobrava hantavirus from a patient with severe haemorrhagic fever with renal syndrome by SYBR Greenbased real time RT-PCR. Scand J Infect Dis. 2007;39(10): 902-6, http://dx.doi.org/10.1080/00365540701387072.

16. Jakab F, Sebok J, Szántó Z, Hang D, Imre M, Németh V, et al. Dobrava-Belgrade hantavirus infection mimics acute appendicitis. J Clin Virol. 2011;50(2):164-6, http://dx.doi. org/10.1016/j.jcv.2010.10.009.

17. Oldal M, Németh V, Madai M, Kemenesi G, Dallos B, Péterfi Z, et al. Identification of hantavirus infection by Western blot assay and TaqMan PCR in patients hospitalized with acute kidney injury. Diagn Microbiol Infect Dis. 2014;79(2):166-70, http://dx.doi.org/10.1016/j.diagmicrobio. 2014.01.032.

18. Jakab F, Horváth G, Ferenczi E, Sebok J, Varecza Z, Szucs G. Detection of Dobrava hantaviruses in Apodemus agrarius mice in the Transdanubian region of Hungary. Virus Res. 2007;128(1-2):149-52, http://dx.doi.org/10.1016/ j.virusres.2007.04.015.
19. Scharninghausen JJ, Meyer H, Pfeffer M, Davis DS, Honeycutt RL. Genetic evidence of Dobrava virus in Apodemus agrarius in Hungary. Emerg Infect Dis. 1999;5(3):468-70, http://dx.doi.org/10.3201/eid0503.990324.

20. Németh V, Oldal M, Madai M, Horváth G, Kemenesi G, Dallos B, et al. Molecular characterization of Dobrava and Kurkino genotypes of Dobrava-Belgrade hantavirus detected in Hungary and Northern Croatia. Virus Genes. 2013;47(3): 546-9, http://dx.doi.org/10.1007/s11262-013-0963-6.

21. Jakab F, Horváth G, Ferenczi E, Sebok J, Szucs G. First detection of Tula hantaviruses in Microtus arvalis voles in Hungary. Arch Virol. 2008;153(11):2093-6, http://dx.doi. org/10.1007/s00705-008-0216-5.

22. Kang HJ, Bennett SN, Sumibcay L, Arai S, Hope AG, Mocz G, et al. Evolutionary insights from a genetically divergent hantavirus harbored by the European common mole (Talpa europaea). PLoS One. 2009;4(7):e6149, http://dx.doi. org/10.1371/journal.pone.0006149.

23. Kang HJ, Arai S, Hope AG, Song JW, Cook JA, Yanagihara R. Genetic diversity and phylogeography of Seewis virus in the Eurasian common shrew in Finland and Hungary. Virol J. 2009;6:208, http://dx.doi.org/10.1186/1743-422X-6-208.

24. Sibold C, Meisel H, Lundkvist A, Schulz A, Cifire F, Ulrich R, et al. Short report: Simultaneous occurrence of Dobrava, Puumala, and Tula Hantaviruses in Slovakia. Am J Trop Med Hyg. 1999;61(3):409-11.

25. Gut W, Siennicka J, Sadkowska-Todys M, Baumann A, Litwińska B. [Hantavirus specific IgG antibodies in population of zoologists and forest workers]. Przegl Epidemiol. 2007;61(3):483-8. Polish.

26. Grygorczuk S, Pancewicz S, Zajkowska J, Kondrusik M, Swierzbińska R, Moniuszko A, et al. [Detection of antihantavirus antibodies in forest workers in the north-east of Poland]. Przegl Epidemiol. 2008;62(3):531-7. Polish.

27. Schultze D, Fierz W, Matter HC, Bankoul S, Niedrig M, Schmiedl A. Cross-sectional survey on hantavirus seroprevalence in Canton St. Gallen, Switzerland. Swiss Med Wkly. 2007;137(1-2):21-6. 
28. Mertens M, Hofmann J, Petraityte-Burneikiene R, Ziller M, Sasnauskas K, Friedrich R, et al. Seroprevalence study in forestry workers of a non-endemic region in eastern Germany reveals infections by Tula and Dobrava-Belgrade hantaviruses. Med Microbiol Immunol. 2011;200(4):263-8, http:// dx.doi.org/10.1007/s00430-011-0203-4.

29. Németh V, Madai M, Maráczi A, Bérczi B, Horváth G, Oldal M, et al. Detection of Dobrava-Belgrade hantavirus using recombinant-nucleocapsid-based enzyme-linked immunosorbent assay and SYBR Green-based real-time reverse transcriptase-polymerase chain reaction. Arch Virol. 2011;156(9):1655-60, http://dx.doi.org/10.1007/s00705-0111013-0.

30. Dobly A, Cochez C, Goossens E, de Bosschere H, Hansen P, Roels S, et al. Sero-epidemiological study of the presence of hantaviruses in domestic dogs and cats from Belgium. Res Vet Sci. 2012;92(2):221-4, http://dx.doi.org/10.1016/ j.rvsc.2011.02.003.
31. Suchomel J. Contribution to the knowledge of Clethrionomys glareolus populations in forests of managed landscape in Southern Moravia (Czech Republic). J For Sci. 2007;53(7):340-4.

32. Trubenovį K, Miklós P. Population ecology of Apodemus flavicollis in a montane beech-spruce forest in the western Tatra mountains. Acta Univ Comen. 2007;47(1):83-90.

33. Ferenczi E, Rácz G, Szekeres J, Balog K, Tóth E, Takács M, et al. New data for the public health importance of hantaviruses in Hungary. Orv Hetil. 2003;144(10):467-74.

34. Heyman P, Ceianu CS, Christova I, Tordo N, Beersma M, João Alves M, et al. A five-year perspective on the situation of haemorrhagic fever with renal syndrome and status of the hantavirus reservoirs in Europe, 2005-2010. Euro Surveill. 2011;16(36):pii:19961.

35. Krüger DH, Ulrich RG, Hofmann J. Hantaviruses as zoonotic pathogens in Germany. Dtsch Arztebl Int. 2013;110: 461-7, http://dx.doi.org/10.3238/arztebl.2013.0461.

This work is available in Open Access model and licensed under a Creative Commons Attribution-NonCommercial 3.0 Poland License - http://creativecommons.org/ licenses/by-nc/3.0/pl/deed.en. 